
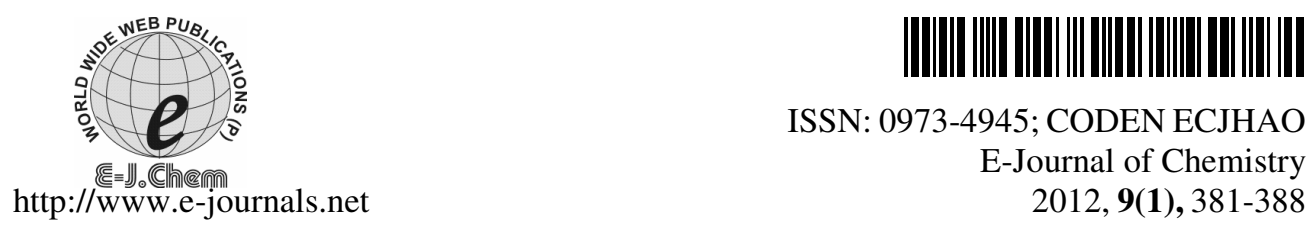

ISSN: 0973-4945; CODEN ECJHAO

E-Journal of Chemistry

2012, 9(1), 381-388

\title{
Direct Electrochemical Synthesis of Bismuth(III) Phenoxides and their Coordination Compounds
}

\author{
HARPREET KAUR and BALJIT SINGH* \\ Chemistry Department \\ Punjabi University, Patiala-147002, India \\ baljit_chemz@yahoo.co.in
}

Received 21 March 2011; Accepted 30 April 2011

\begin{abstract}
Bismuth(III) phenoxides have been synthesized by electrochemical reactions of 1-naphthol, 2-naphthol, 4-aminophenol, 2-nitrophenol, 4-nitrophenol, 2-hydroxybenzoic acid, $p$-cresol, phenol, resorcinol, 2-tert-butylphenol and 2-tert-butyl-4-methoxyphenol at sacrificial bismuth anode and inert platinum cathode using tetrabutylammonium chloride as supporting electrolyte. The coordination compounds of these phenols with 1, 10-phenanthroline and 2, 2'-bipyridyl have also been synthesized electrochemically. The solid products separated in the anode compartment have been isolated and characterized by elemental analysis and infrared spectral studies. Current efficiencies of these reactions are quite high.
\end{abstract}

Keywords: Electrochemical synthesis, Sacrificial electrode, $H$-type cell, Tetrabutylammonium chloride, Current efficiencies

\section{Introduction}

Electrochemical technique has widely been used in synthetic organic ${ }^{1-5}$ and inorganic chemistry $^{6-10}$. This technique is the direct route to carry out oxidation or reduction without introducing any foreign oxidizing or reducing agent. The most important advantages of this technique are the simplicity and high product yield. In continuation to our interest in the electrochemical synthesis of inorganic compounds ${ }^{11-13}$, we report in this communication the synthesis of bismuth phenoxides and their coordination compounds.

\section{Experimental}

Acetonitrile was kept over phosphorus pentoxide for $24 \mathrm{~h}$ and then double distilled. Freshly distilled acetonitrile was used as solvent in all these reactions. Tetrabutylammonium chloride (Reidal pure) was crystallized from conductivity water and dried under reduced pressure at $100{ }^{\circ} \mathrm{C}$. It was then used as supporting electrolyte in all these reactions. 
A $H$-type cell made of pyrex glass in which the cathode and anode compartments were separated from each other by a sintered glass disc of G-3 porosity, was used as the reaction vessel. Both compartments were provided with two openings; one for guard tube and the other for electrode. Platinum guage $\left(2.0 \times 1.0 \times 1.0 \mathrm{~cm}^{3}\right)$ was used as cathode and bismuth rod $\left(2.0 \times 10.0 \times 0.2 \mathrm{~cm}^{3}\right)$ as anode. Direct current was obtained with the help of toshniwal electrophoresis power supply. The electrolytic solution in the anode compartment was stirred efficiently using magnetic stirrer.

$1.0 \mathrm{~g}$ of Phenols, $1.0 \mathrm{~g}$ of tetrabutylammonium chloride and $250 \mathrm{~mL}$ of freshly distilled acetonitrile were taken in the $H$-type cell. Bismuth metal electrode was dipped in anode compartment and platinum guage in the cathode compartment and outlets were sealed after fitting the guard tubes. Necessary connections were made with power supply and potential across the electrodes was then adjusted so that a current of $20 \mathrm{~mA}$ passed through the solution. The cell can be represented as:

Where:

$$
\mathrm{Bi}(+)\left|\begin{array}{c}
\mathrm{CH}_{3} \mathrm{CN}+\mathrm{Bu}_{4} \mathrm{NCI}+\mathrm{Pt}(-) \\
\text { Phenols }
\end{array}\right|
$$

$\mathrm{Bi}(+)$ is Bismuth anode.

$\mathrm{Pt}(-)$ is Platinum cathode.

$\mathrm{Bu}_{4} \mathrm{NCl}$ is supporting electrolyte.

The electrolysis was carried out with continuous stirring in the anode compartment. After conducting electrolysis for twelve hours, the product was filtered, washed with hot acetonitrile and dry ether and finally dried under vacuum.

The current efficiencies (gram equivalents of metal dissolved per faraday of electricity passed) of all these reactions were determined by electrolyzing the above systems for exactly two hours at a constant current of $20 \mathrm{~mA}$ as reported earlier ${ }^{11-13}$. Melting point of all these products was recorded using electrical device with heating rate of $5{ }^{\circ} \mathrm{C}$ per minute.

Infrared spectra of the products were recorded on Perkin-Elmer spectrophotometer (RXI) in the region of $4000-450 \mathrm{~cm}^{-1}$ using potassium bromide pellets. The products were analyzed for bismuth contents. Weighed amount of the product was heated to dry mass with fuming nitric acid six times. The dry mass was dissolved in few drops of dilute nitric acid and $100 \mathrm{~mL}$ solution was made. The contents of bismuth in solution were estimated volumetrically by oxine method ${ }^{14}$. The microanalyses of $\mathrm{C}, \mathrm{H}$ and $\mathrm{N}$ of these compounds have also been carried out.

\section{Results and Discussion}

The products obtained are insoluble in commonly used organic solvents like chloroform, benzene, methanol, acetone, dimethyl sulphoxide, $N, N$-dimethyl formamide etc. All these compounds do not melt up to $300{ }^{\circ} \mathrm{C}$, however, colour of these compounds changes around $230^{\circ} \mathrm{C}$ thereby indicating that these products decompose around this temperature.

The analytical data (bismuth, carbon, hydrogen and nitrogen contents in all these products) along with their electrolytic characteristics of these systems are summarized in Table 1. Perusal of Table 1 reveals that the analytical data conform to the molecular formula $\mathrm{Bi}(\mathrm{OPhX})_{3}$ where $\mathrm{X}$ is $\mathrm{NH}_{2}, \mathrm{NO}_{2}, 2$-tertbutyl and 2-tertbutyl-4-methoxy groups in various phenols except in case of 2-hydroxybenzoic acid where $\mathrm{X}$ denotes $\mathrm{OH}$ group.

Infrared spectra of all the electrochemical products (except that of 2-hydroxybenzoic acid) show no absorption band in the region of $3600-3400 \mathrm{~cm}^{-1}$ thereby showing that the proton of phenolic group ${ }^{15}$ in these reactions has been replaced by anodic bismuth. All the products show absorption bands in the region of $680-670 \mathrm{~cm}^{-1}$. Literature reveals ${ }^{15-17}$ that 
the $v(\mathrm{M}-\mathrm{O})$ stretching bands appear in the region of $700-500 \mathrm{~cm}^{-1}$. Thus these bands appearing in the region of $680-670 \mathrm{~cm}^{-1}$ can be assigned to $v(\mathrm{Bi}-\mathrm{O})$ stretching vibrations ${ }^{18-19}$. Survey of literature reveals ${ }^{20}$ that in metal aryloxides two types of bands due to $v(\mathrm{C}-\mathrm{O}) \mathrm{M}$ appear in the region of $1180-1010 \mathrm{~cm}^{-1}$. In the present products two types of bands appear in the region of $1158-1030 \mathrm{~cm}^{-1}$ due to $v(\mathrm{C}-\mathrm{O}) \mathrm{Bi}$ stretching vibrations. Bands in the region of $1158-1060 \mathrm{~cm}^{-1}$ may be assigned to terminal $v(\mathrm{C}-\mathrm{O}) \mathrm{Bi}$ phenoxy groups and the bands in the region of 1060-1030 $\mathrm{cm}^{-1}$ may be attributes to bridged $v(\mathrm{C}-\mathrm{O}) \mathrm{Bi}$ phenoxy groups.

Table 1. Electrolysis characteristics, analytical and other related data of electrolysis of phenols at bismuth anode

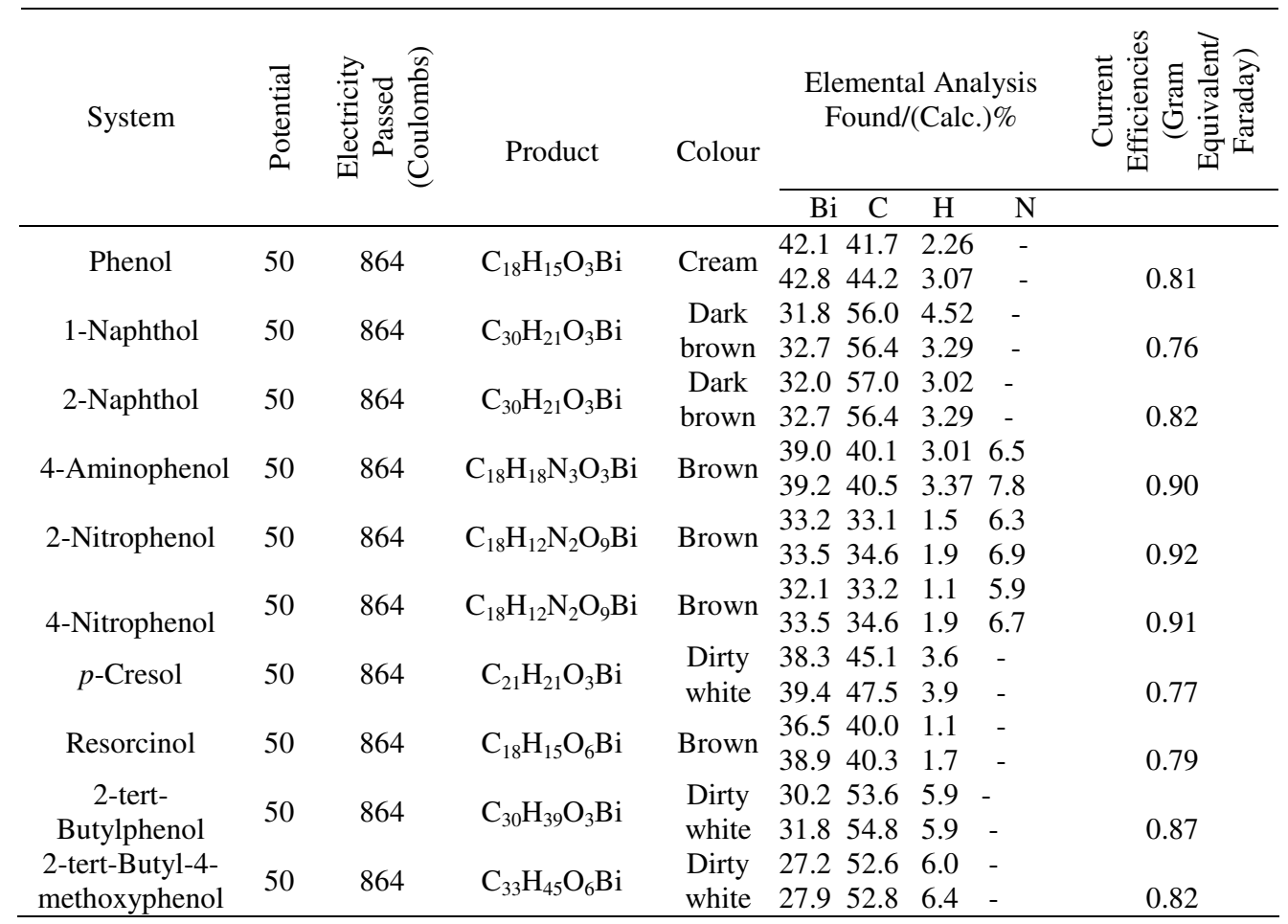

Presence of bands due to bridged phenoxy groups in the infrared spectra of the products indicates their polymeric nature. Polymeric nature of the products is also supported by their high melting point and insoluble behaviour in various organic solvents.

The infrared spectral data of the electrochemical product of 2-hydroxybenzoic acid show characteristic bands at $3575 \mathrm{~cm}^{-1}, 1653 \mathrm{~cm}^{-1}$ and $1315 \mathrm{~cm}^{-1}$. The band at $3575 \mathrm{~cm}^{-1}$ indicates that hydroxyl proton of 2-hydroxybenzoic acid is not replaced by anodic bismuth. Literature also reveals ${ }^{21}$ that carboxylate groups show characteristic absorption bands in the region of $1647-1636 \mathrm{~cm}^{-1}, 1318-1308 \mathrm{~cm}^{-1}$ corresponding to asymmetric and symmetric stretching vibrations. The presence of bands at $1653 \mathrm{~cm}^{-1}$ and $1315 \mathrm{~cm}^{-1}$ in the present product thus can be assigned to asymmetric and symmetric stretching vibrations. Since the carboxylic group is more acidic than phenolic group, thus the proton of carboxylic group is replaced by anodic bismuth and phenolic group remains unaffected. In this product bands also appear at $1178 \mathrm{~cm}^{-1}$, $1140 \mathrm{~cm}^{-1}, 1058 \mathrm{~cm}^{-1}$ and $677 \mathrm{~cm}^{-1}$ which can be assigned to bridged $v(\mathrm{Bi}-\mathrm{OH})^{22}$, terminal $v(\mathrm{C}-\mathrm{O}) \mathrm{Bi}$, bridged $v(\mathrm{C}-\mathrm{O}) \mathrm{Bi}$ and $v(\mathrm{Bi}-\mathrm{O})$ mode $^{18-19}$ respectively. 
Current efficiencies of these systems were also determined and are enlisted in Table 1. Perusal of Table 1 reveals that current efficiencies of various phenols at sacrificial bismuth anode are quite high. High current efficiencies of these systems indicate that the reactions leading to the formation of bismuth(III) phenoxides are the predominant reactions of these systems. The reaction scheme may be written as:

At inert cathode:

3<smiles>Oc1ccccc1</smiles><smiles>[3H][TeH]</smiles>

At sacrificial bismuth anode:

3<smiles>[O-]c1ccccc1</smiles><smiles>[C+]1[C+]CC1</smiles><smiles>CCCCCCCC</smiles>

3<smiles>[X]c1cccc([O-])c1</smiles>

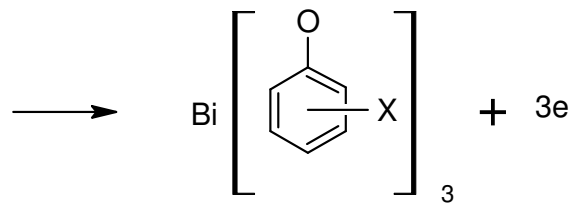

In case of 2-hydroxybenzoic acid, since the carboxylic group is easily reducible than phenolic group so reaction scheme may be written as:

At inert cathode:

3<smiles>O=C(O)c1ccccc1O</smiles>

At sacrificial bismuth anode:

3<smiles>O=C([O-])c1ccccc1O</smiles><smiles>C1CC1</smiles>

3<smiles>O=C([O-])c1ccccc1O</smiles>

\section{Synthesis of coordination compounds}

Electrochemically prepared bismuth(III) phenoxides have been refluxed with the ligand (1,10-phenanthroline or 2,2'-bipyridyl) in various solvents for $48 \mathrm{~h}$ in order to prepare coordination compounds of these phenoxides. Analytical data and infrared spectral data of these products show that no coordination products have been formed. It was, therefore, considered worthwhile that the ligand may be added to these phenoxides before these form phenoxy bridges. Therefore, in addition to the phenols and supporting electrolyte, $1.0 \mathrm{~g}$ of the ligand was also added to these systems and the solution was then electrolysed at bismuth anode.

The solid product separated in anode compartment was filtered, washed with dry ether and dried under vacuum. The analytical data (bismuth, carbon, hydrogen and nitrogen contents in all these products) along with there electrolytic characteristics of these systems are summarized in Table 2 and Table 3. The data conform to molecular formula $\mathrm{Bi}(\mathrm{OPhX})_{3} \mathrm{~L}$.

The products obtained are insoluble in commonly used organic solvents. Melting point of all these products has also been determined. All these compounds do not melt up to $300{ }^{\circ} \mathrm{C}$, however, colour of these compounds changes around $230{ }^{\circ} \mathrm{C}$ thereby indicating that these products decompose around this temperature. 
Table 2. Electrolysis characteristics, analytical and other related data of electrolytic product of various phenol systems $+1,10$-phenanthroline at bismuth anode

\begin{tabular}{|c|c|c|c|c|c|c|c|c|c|}
\hline \multirow{2}{*}{ System } & \multirow{2}{*}{$\begin{array}{l}\stackrel{\text { ज्ञ }}{0} \\
0 \\
0 \\
0\end{array}$} & \multirow{2}{*}{ 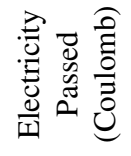 } & \multirow{2}{*}{ Product } & \multirow{2}{*}{ Colour } & \multicolumn{4}{|c|}{$\begin{array}{l}\text { Elemental Analysis } \\
\text { Found } /(\text { Calc. }) \%\end{array}$} & \multirow{2}{*}{ 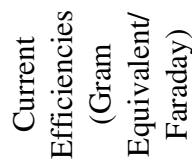 } \\
\hline & & & & & $\mathrm{Bi}$ & $\mathrm{C}$ & $\mathrm{H}$ & $\mathrm{N}$ & \\
\hline \multirow{2}{*}{$\begin{array}{c}\text { Phenol + 1, } \\
\text { 10-phenanthroline }\end{array}$} & \multirow{2}{*}{50} & \multirow{2}{*}{864} & \multirow{2}{*}{$\mathrm{C}_{30} \mathrm{H}_{25} \mathrm{~N}_{2} \mathrm{O}_{4} \mathrm{Bi}$} & \multirow{2}{*}{ Brown } & 29.1 & 51.7 & 3.2 & 3.5 & \\
\hline & & & & & 30.5 & 52.5 & 3.6 & 4.1 & 0.81 \\
\hline 1-Naphthol + 1, & \multirow{2}{*}{50} & \multirow{2}{*}{864} & \multirow{2}{*}{$\mathrm{C}_{42} \mathrm{H}_{31} \mathrm{~N}_{28} \mathrm{O}_{4} \mathrm{Bi}$} & Dark & 24.3 & 59.8 & 2.7 & 3.0 & \\
\hline 10-phenanthroline & & & & brown & 24.9 & 60.3 & 3.7 & 3.3 & 0.86 \\
\hline 2-Naphthol + 1, & \multirow{2}{*}{50} & \multirow{2}{*}{864} & \multirow{2}{*}{$\mathrm{C}_{42} \mathrm{H}_{31} \mathrm{~N}_{28} \mathrm{O}_{4} \mathrm{Bi}$} & \multirow{2}{*}{ Brown } & 24.1 & 60.0 & 3.2 & 2.8 & \\
\hline 10-phenanthroline & & & & & 24.9 & 60.3 & 3.7 & 3.3 & 0.88 \\
\hline 4-Aminophenol + & \multirow{2}{*}{50} & \multirow{2}{*}{864} & \multirow{2}{*}{$\mathrm{C}_{30} \mathrm{H}_{28} \mathrm{~N}_{5} \mathrm{O}_{4} \mathrm{Bi}$} & \multirow{2}{*}{ Cream } & 27.3 & 46.1 & 3.0 & 9.5 & \\
\hline 1,10-henanthroline & & & & & 28.6 & 49.2 & 3.8 & 9.6 & 0.89 \\
\hline 2-Nitrophenol + & \multirow[t]{2}{*}{50} & \multirow{2}{*}{864} & \multirow{2}{*}{$\mathrm{C}_{30} \mathrm{H}_{22} \mathrm{~N}_{5} \mathrm{O}_{10} \mathrm{Bi}$} & \multirow{2}{*}{ Brown } & 25.2 & 40.1 & 2.5 & 8.3 & \\
\hline 1,10-henanthroline & & & & & 25.4 & 43.8 & 2.6 & 8.5 & 0.92 \\
\hline 4-Nitrophenol + & \multirow{2}{*}{50} & \multirow[t]{2}{*}{864} & \multirow{2}{*}{$\mathrm{C}_{30} \mathrm{H}_{22} \mathrm{~N}_{5} \mathrm{O}_{10} \mathrm{Bi}$} & \multirow{2}{*}{ Brown } & 24.9 & 42.6 & 1.9 & 8.6 & \\
\hline 1,10-henanthroline & & & & & 25.4 & 43.8 & 2.6 & 8.5 & 0.91 \\
\hline$p$-Cresol + 1, & \multirow[t]{2}{*}{50} & 864 & $\mathrm{C}_{33} \mathrm{H}_{31} \mathrm{~N}_{28} \mathrm{O}_{4} \mathrm{Bi}$ & Cream & 28.3 & 54.1 & 3.6 & 3.3 & \\
\hline 10-phenanthroline & & & & & 28.7 & 54.4 & 4.2 & 3.9 & 0.71 \\
\hline Resorcinol + 1, & 50 & 864 & $\mathrm{C}_{30} \mathrm{H}_{28} \mathrm{~N}_{28} \mathrm{O}_{7} \mathrm{Bi}$ & Brown & 27.5 & 45.0 & 2.0 & 3.7 & \\
\hline $\begin{array}{l}\text { 10-phenanthroline } \\
\text { 2-tert- Butylpheno }\end{array}$ & & & & & 28.5 & 49.0 & 3.8 & 3.8 & 0.72 \\
\hline $\begin{array}{l}\text { 2-tert- Butylpheno } \\
\quad+1,10-\end{array}$ & 50 & 864 & $\mathrm{C}_{42} \mathrm{H}_{49} \mathrm{~N}_{2} \mathrm{O}_{4} \mathrm{Bi}$ & Dar & 24.2 & 55.6 & 5.9 & 3.1 & \\
\hline $\begin{array}{l}\text { phenanthroline } \\
\text { 2-tert-Butyl-4- }\end{array}$ & & & & bro & 24.5 & 59.0 & 5.7 & 3.3 & 0.87 \\
\hline methoxyphenol + & 50 & 864 & $\mathrm{C}_{45} \mathrm{H}_{58} \mathrm{~N}_{2} \mathrm{O}_{7} \mathrm{Bi}$ & Dark & 22.2 & 55.6 & 5.9 & 2.2 & \\
\hline $\begin{array}{c}1,10- \\
\text { phenanthroline }\end{array}$ & & & & brown & 22.1 & 57.0 & 6.1 & 2.9 & 0.88 \\
\hline $\begin{array}{l}\text { 2-Hydroxybenzoic } \\
\text { acid }+1\end{array}$ & 50 & 864 & & rown & 27.2 & 51.6 & 2.9 & 2.9 & \\
\hline 10-phenanthroline & & & $C_{33} \Pi$ & DIOWII & 27.1 & 51.4 & 3.2 & 3.6 & 0.72 \\
\hline
\end{tabular}

Infrared spectral data of these products (except that of 2-hydroxybenzoic acid) show no absorption band corresponding to phenolic group ${ }^{15}$. Examination of infrared data of the products reveals that the characteristic bands appear in the regions of $690-680 \mathrm{~cm}^{-1}$, $1070-1035 \mathrm{~cm}^{-1} 1070-1165 \mathrm{~cm}^{-1}$ and $1605-1585 \mathrm{~cm}^{-1}$. The bands in the region of $690-680 \mathrm{~cm}^{-1}$, $1070-1035 \mathrm{~cm}^{-1}$ and $1070-1165 \mathrm{~cm}^{-1}$, may be assigned to $v(\mathrm{Bi}-\mathrm{O})^{18-19}, v(\mathrm{C}-\mathrm{O})$ Bi bridged and $v(\mathrm{C}-\mathrm{O}) \mathrm{Bi}$ terminal stretching mode ${ }^{20}$ respectively. All these bands, however, appear in slightly higher region as compared to those in the parent phenoxides.

The additional bands observed in the infrared spectra of these products in the region of $1605-1585 \mathrm{~cm}^{-1}$ are due to the ligand molecules and can be assigned to $v(\mathrm{C}-\mathrm{N})$ and $v(\mathrm{C}-\mathrm{C})$ stretching vibrations ${ }^{22}$. These bands also appear at slightly higher region as compared to those in the parent ligand molecules.

In case of coordination products of 2-hydroxybenzoic acid infrared data show absorption band in the region of $3360-3350 \mathrm{~cm}^{-1}$ corresponding to phenolic group ${ }^{23}$ and characteristic absorption bands due to carboxylate group in the region of $1642-1641 \mathrm{~cm}^{-1}$ and 1315-1307 $\mathrm{cm}^{-1}$ correspond to asymmetric and symmetric stretching vibrations respectively. In these products, bands also appear in the region of $690-680 \mathrm{~cm}^{-1}$ due to 
$v(\mathrm{Bi}-\mathrm{O})^{18-19}, 1075-1048 \mathrm{~cm}^{-1}$ due to bridged $v(\mathrm{C}-\mathrm{O}) \mathrm{Bi}, 1075-1178 \mathrm{~cm}^{-1}$ correspond to terminal $v(\mathrm{C}-\mathrm{O}) \mathrm{Bi}, 1183-1182 \mathrm{~cm}^{-1}$ due to bridged $v(\mathrm{Bi}-\mathrm{OH})^{22}$ and $1605-1595 \mathrm{~cm}^{-1}$ due to $v(\mathrm{C}-\mathrm{N})$ and $v(\mathrm{C}-\mathrm{C})$ stretching vibrations respectively.

Table 3. Electrolysis characteristics, analytical and other related data of electrolytic product of various phenol systems $+2,2^{\prime}$ - bipyridyl at bismuth anode

\begin{tabular}{|c|c|c|c|c|c|c|c|c|c|}
\hline \multirow{2}{*}{ System } & \multirow{2}{*}{ 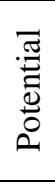 } & \multirow{2}{*}{ 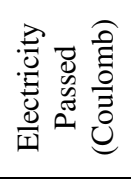 } & \multirow[b]{2}{*}{ Product } & \multirow[b]{2}{*}{ Colour } & \multicolumn{4}{|c|}{$\begin{array}{l}\text { Elemental Analysis } \\
\text { Found/(Calc.)\% }\end{array}$} & \multirow{2}{*}{$\begin{array}{c}\text { Current } \\
\text { Efficiencies } \\
\text { (Gram } \\
\text { Equivalent/ } \\
\text { Faraday) } \\
\end{array}$} \\
\hline & & & & & $\mathrm{Bi}$ & $\mathrm{C}$ & $\mathrm{H}$ & $\mathrm{N}$ & \\
\hline $\begin{array}{c}\text { Phenol }+ \\
\text { 2, 2' - bipyridyl }\end{array}$ & 50 & 864 & $\mathrm{C}_{28} \mathrm{H}_{23} \mathrm{~N}_{2} \mathrm{O}_{3} \mathrm{Bi}$ & Brown & $\begin{array}{l}32.1 \\
32.4\end{array}$ & $\begin{array}{l}51.7 \\
52.1\end{array}$ & $\begin{array}{l}3.2 \\
3.5\end{array}$ & $\begin{array}{l}4.1 \\
4.4\end{array}$ & 0.81 \\
\hline $\begin{array}{c}\text { 1-Naphthol + } \\
2,2^{\prime} \text { - bipyridyl }\end{array}$ & 50 & 864 & $\mathrm{C}_{40} \mathrm{H}_{29} \mathrm{~N}_{2} \mathrm{O}_{3} \mathrm{Bi}$ & Brown & $\begin{array}{l}26.8 \\
26.3\end{array}$ & $\begin{array}{l}59.0 \\
60.4\end{array}$ & $\begin{array}{l}3.5 \\
3.6\end{array}$ & $\begin{array}{l}3.4 \\
3.5\end{array}$ & 0.79 \\
\hline $\begin{array}{c}\text { 2-Naphthol + } \\
\text { 2,2'- bipyridyl }\end{array}$ & 50 & 864 & $\mathrm{C}_{40} \mathrm{H}_{29} \mathrm{~N}_{2} \mathrm{O}_{3} \mathrm{Bi}$ & $\begin{array}{c}\text { Dark } \\
\text { brown }\end{array}$ & $\begin{array}{l}26.0 \\
26.3\end{array}$ & $\begin{array}{l}58.9 \\
60.4\end{array}$ & $\begin{array}{l}3.0 \\
3.6\end{array}$ & $\begin{array}{l}2.9 \\
3.5\end{array}$ & 0.82 \\
\hline $\begin{array}{c}\text { 4-Aminophenol + } \\
2,2^{\prime}-\text { bipyridyl }\end{array}$ & 50 & 864 & $\mathrm{C}_{28} \mathrm{H}_{26} \mathrm{~N}_{5} \mathrm{O}_{3} \mathrm{Bi}$ & Cream & $\begin{array}{l}30.0 \\
30.3\end{array}$ & $\begin{array}{l}46.1 \\
48.8\end{array}$ & $\begin{array}{ll}1 & 3.0 \\
8 & 3.71\end{array}$ & $\begin{array}{r}9.5 \\
10.2\end{array}$ & 0.91 \\
\hline $\begin{array}{l}\text { 2-Nitrophenol + } \\
\text { 2,2' - bipyridyl }\end{array}$ & 50 & 864 & $\mathrm{C}_{28} \mathrm{H}_{20} \mathrm{~N}_{5} \mathrm{O}_{9} \mathrm{Bi}$ & Brown & $\begin{array}{l}25.2 \\
26.8\end{array}$ & $\begin{array}{l}41.1 \\
43.1\end{array}$ & $\begin{array}{ll}1 & 1.5 \\
1 & 2.5\end{array}$ & $\begin{array}{l}8.3 \\
8.9\end{array}$ & 0.82 \\
\hline $\begin{array}{l}\text { 4-Nitrophenol + } \\
\text { 2,2' - bipyridyl }\end{array}$ & 50 & 864 & $\mathrm{C}_{28} \mathrm{H}_{20} \mathrm{~N}_{5} \mathrm{O}_{9} \mathrm{Bi}$ & Cream & $\begin{array}{l}26.1 \\
26.8\end{array}$ & $\begin{array}{l}43.2 \\
43.1\end{array}$ & $\begin{array}{ll}2 & 2.1 \\
1 & 2.5\end{array}$ & $\begin{array}{l}7.9 \\
8.9\end{array}$ & 0.86 \\
\hline $\begin{array}{c}p \text {-Cresol + } \\
2,2^{\prime} \text { - bipyridyl }\end{array}$ & 50 & 864 & $\mathrm{C}_{31} \mathrm{H}_{29} \mathrm{~N}_{2} \mathrm{O}_{3} \mathrm{Bi}$ & Brown & $\begin{array}{l}30.3 \\
30.5\end{array}$ & $\begin{array}{l}52.1 \\
54.2\end{array}$ & $\begin{array}{ll}1 & 4.0 \\
2 & 4.2\end{array}$ & $\begin{array}{l}4.2 \\
4.1\end{array}$ & 0.71 \\
\hline $\begin{array}{c}\text { Resorcinol + } \\
\text { 2,2' - bipyridyl }\end{array}$ & 50 & 864 & $\mathrm{C}_{28} \mathrm{H}_{23} \mathrm{~N}_{2} \mathrm{O}_{6} \mathrm{Bi}$ & Brown & $\begin{array}{l}30.0 \\
30.2\end{array}$ & $\begin{array}{l}47.9 \\
48.5\end{array}$ & $\begin{array}{ll}9 & 2.9 \\
5 & 3.3\end{array}$ & $\begin{array}{l}4.1 \\
4.0\end{array}$ & 0.72 \\
\hline $\begin{array}{c}2 \text {-tert- } \\
\text { Butylphenol + } 2 \\
2^{\prime}-\text { bipyridyl }\end{array}$ & 50 & 864 & $\mathrm{C}_{40} \mathrm{H}_{47} \mathrm{~N}_{2} \mathrm{O}_{3} \mathrm{Bi}$ & Brown & $\begin{array}{l}24.9 \\
25.7\end{array}$ & $\begin{array}{l}55.6 \\
59.1\end{array}$ & $\begin{array}{ll}6 & 5.9 \\
1 & 5.7\end{array}$ & $\begin{array}{l}2.8 \\
3.5\end{array}$ & 0.90 \\
\hline $\begin{array}{l}\text { 2-tert-Butyl-4- } \\
\text { methoxyphenol + } \\
\text { 2,2' - bipyridyl }\end{array}$ & 50 & 864 & $\mathrm{C}_{43} \mathrm{H}_{56} \mathrm{~N}_{2} \mathrm{O}_{6} \mathrm{Bi}$ & $\begin{array}{c}\text { Dark } \\
\text { brown }\end{array}$ & $\begin{array}{l}23.2 \\
23.1\end{array}$ & $\begin{array}{l}57.6 \\
57.0\end{array}$ & $\begin{array}{ll}6 & 6.9 \\
0 & 6.1\end{array}$ & $\begin{array}{l}3.2 \\
3.1\end{array}$ & 0.88 \\
\hline $\begin{array}{c}\text { 2-Hydroxybenzoic } \\
\text { acid }+ \\
2,2^{\prime} \text { - bipyridyl }\end{array}$ & 50 & 864 & $\mathrm{C}_{31} \mathrm{H}_{23} \mathrm{~N}_{2} \mathrm{O}_{9} \mathrm{Bi}$ & $\begin{array}{c}\text { Dark } \\
\text { brown }\end{array}$ & $\begin{array}{l}27.2 \\
28.6 \\
\end{array}$ & $\begin{array}{l}51.6 \\
51.1 \\
\end{array}$ & $\begin{array}{ll}6 & 3.4 \\
1 & 3.1\end{array}$ & $\begin{array}{l}3.7 \\
3.9 \\
\end{array}$ & 0.82 \\
\hline
\end{tabular}

Shift of the $v(\mathrm{Bi}-\mathrm{O})$ and $v(\mathrm{C}-\mathrm{O}) \mathrm{Bi}$, bands towards higher region and presence of $v(\mathrm{C}-\mathrm{N})$ and $v(\mathrm{C}-\mathrm{C})$ bands confirm the coordination of ligand to bismuth(III) phenolates. Appearance of bands due to terminal phenoxy groups, bridged phenoxy groups, insolublebehaviour in various organic solvents and high melting point indicates that these coordination compounds are also polymeric in nature.

Current efficiencies of all these reactions have been determined and the data are listed in Table 2 and Table 3. Perusal of Table 2 and Table 3 reveals that the current efficiencies of these systems are quite high thereby showing that the reactions leading to the formation of the coordination compounds of bismuth(III) phenolates are the predominant reactions of these systems. The reaction scheme can be given as: 
At inert cathode:

3<smiles>[X]c1cccc(O)c1</smiles>

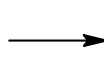

At sacrificial bismuth anode:<smiles>O=C1C=CCCC1</smiles>

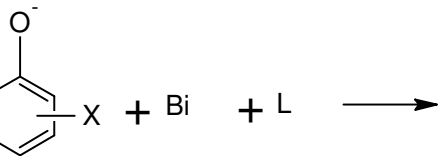

3<smiles>[X]c1cccc([O-])c1</smiles>

The reaction scheme for the 2-hydroxybenzoic acid + ligand system may be written as:

At inert cathode:

3<smiles>O=C(O)c1ccccc1O</smiles>

$$
+3 e
$$

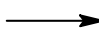

3

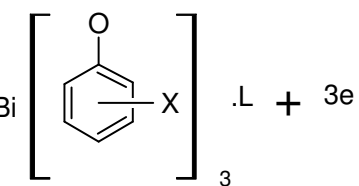

At sacrificial bismuth anode:

3<smiles>O=C([O-])c1ccccc1O</smiles><smiles>[3H][Te][3H]</smiles>

$\mathrm{Bi}$<smiles>O=C(O)c1ccccc1I</smiles>

\section{References}

1. Isuchiya $\mathrm{Y}$ and Fujihara H, Electrochem., 2002, 70, 584-586.

2. Wadhawan Jay D, Marken F, Compton R G, Bull S D and Devies S G, Chem Commun., 2001, 87, 1.

3. Dong-Hun H, Hyo Joong L and Su-Moon P, Electrochimica Acta, 2005, 50(15), 3085-3092.

4. Rehan H A, Polym Int., 2003, 52, 218.

5. Buzarovska A, Arsova I and Arsov L, J Serb Chem Soc., 2001, 66(1), 27-37.

6. Sousa-Padrares A, Romero J and Garcia-Vazquez J A, J Chem Soc Dalton Trans., 2003, 1379.

7. Bell N A, Clegg W and Creighton J R and Raper E S, Inorg Chim Acta, 2002, 58, 225.

8. Bell N A, Clegg W and Creighton J R and E S Raper, Inorg Chim Acta, 2000, 303, 12.

9. Castro J, Cabaleiro S, Perez-Lourido P, Romero J, Garcia-Vazquez J A and Sousa A, Alleg Chem., 2002, 628, 1210.

10. Perez-Lourido P, Romero J, Garcia-Vazquez J A, Sousa A, Maresca K P and Zubieta J, Inorg Chem., 1999, 38, 3709-3715.

11. Singh B and Kaur H, J Indian Chem Soc., 2008, 85, 849-851.

12. Banait J S, Singh B and Rala S, J Indian Chem Soc., 2007, 84(2), 135-138.

13. Banait J S, Singh B and Rala S, J Indian Chem Soc., 2007, 84(1), 25-28.

14. Vogel A I, A Text Book of Quantitative Inorganic analysis, Longman Green, London, 1961.

15. Sharma N, Bose B, Bhatt S S and Chaudhary S C, Synth React Inorg Met-Org Chem., 2001, 31, 1831. 
16. Calabrese J, Cushing M A and Ittel S D, Inorg Chem., 1988, 27(5), 867-870.

17. Boyle T J, Andrews N L, Rodriguez M A, Campana C and Yiu T, Inorg Chem., 2003, 42(17), 5357-5366.

18. Brym M, Jones C and Junk P C, Main Group Chem., 2006, 5(1), 13-19.

19. Hanna T A, Keitany G, Ibarra C, Sommer R D and Rheingold A L, Polyhedron., 2001, 20(19), 2451-2455.

20. Bradley D C, Mehrotra R C, Rothwell I P and Singh A, Alkoxo and Aryloxo Derivatives of Metals, Academic Press, New York, 2001.

21. Khosa M K, Mazahar M, Ali S, Molloy K C, Dastgir S and Shaheen F, Turk J Chem., 2006, 30, 731-743.

22. Kazuo Nakamoto's Application in Coordination, Organometallic and Bioinorganic Chemistry, $5^{\text {th }}$ Edition, Part-B John Wiley and Sons, Inc., 1997.

23. Dyers J R, Application of absorption spectroscopy of organic compounds, Wiley Interscience, New York, 1972. 


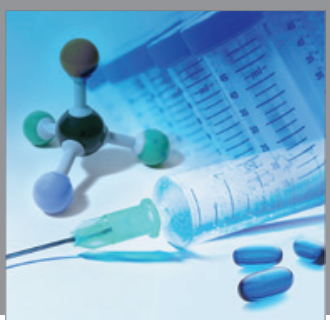

International Journal of

Medicinal Chemistry

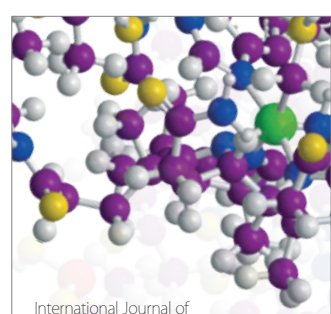

Carbohydrate Chemistry

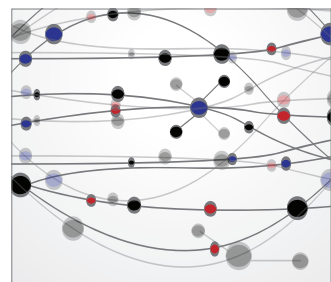

The Scientific World Journal
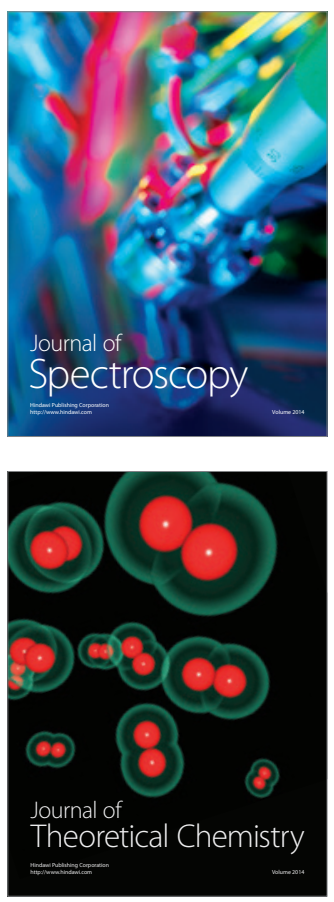
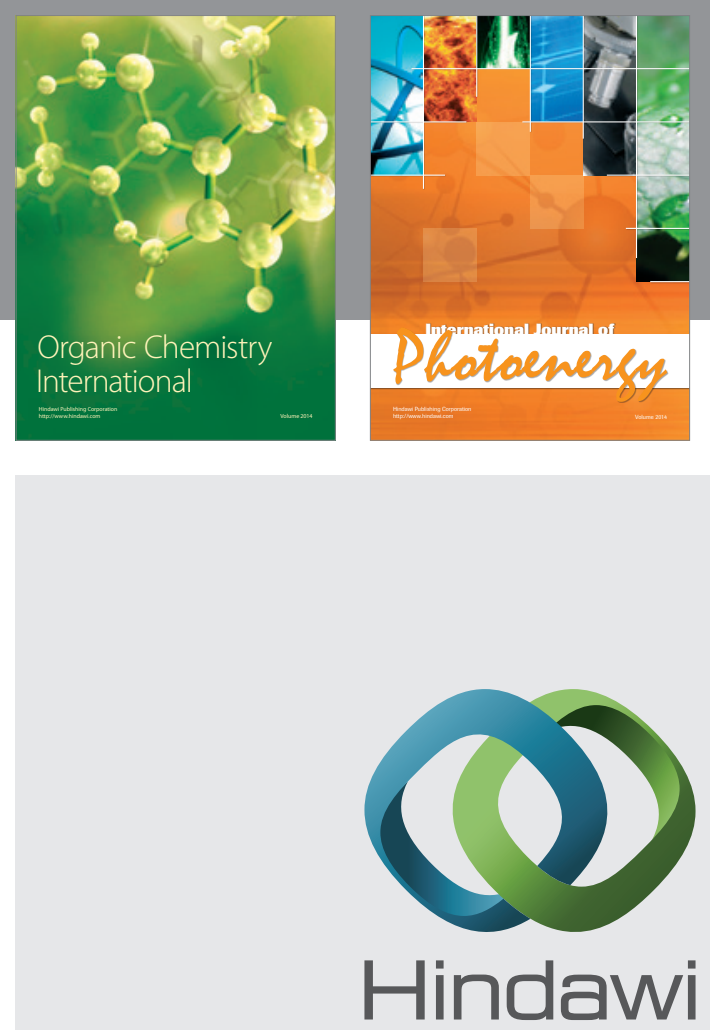

Submit your manuscripts at

http://www.hindawi.com
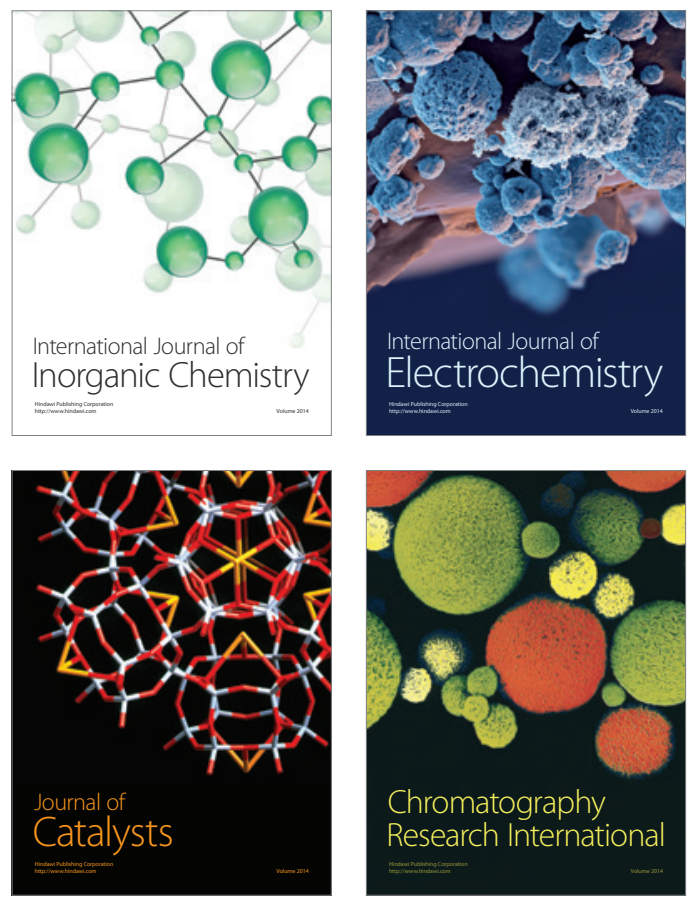
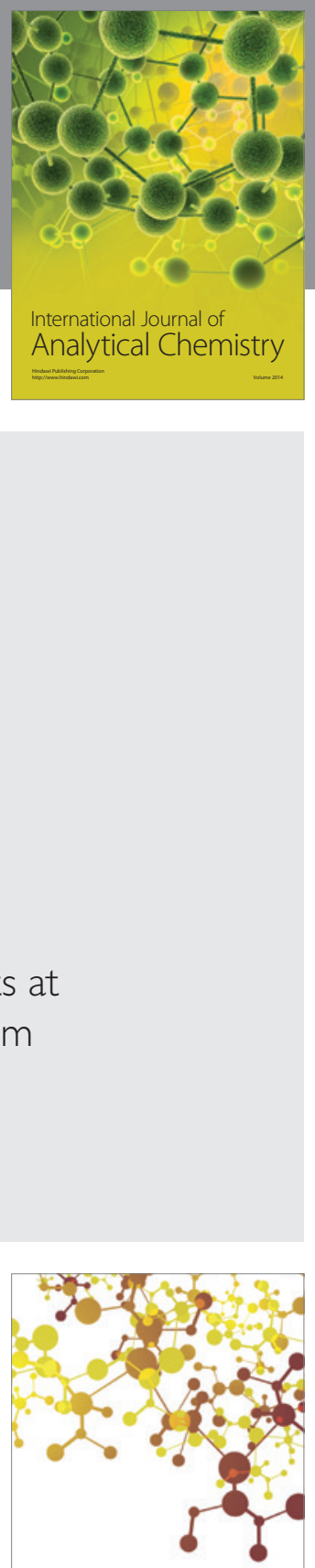

Journal of

Applied Chemistry
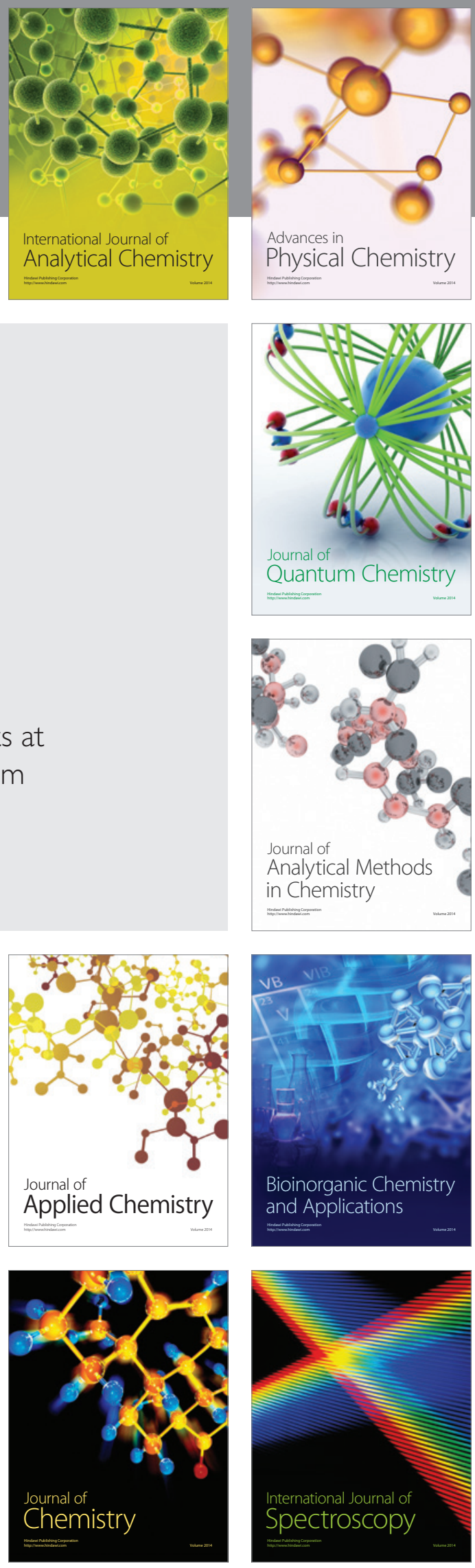